This is a self-archived version of an original article. This version may differ from the original in pagination and typographic details.

Author(s): Salomaa, Elina

Title: Dissertation: "In the intersection of television and Twitter : Social television as a tool for interaction and participation in a media event"

Year: 2020

Version: Accepted version (Final draft)

Copyright: (c) Wilhelm Braumüller, 2020

Rights: In Copyright

Rights url: http://rightsstatements.org/page//nC/1.0/?language=en

Please cite the original version:

Salomaa, E. (2020). Dissertation: "In the intersection of television and Twitter : Social television as a tool for interaction and participation in a media event". Fachsprache, 42(1-2), 72-75.

https://doi.org/10.24989/fs.v42i1-2.1840 


\title{
Dissertation: "In the intersection of television and Twitter: Social television as a tool for interaction and participation in a media event"
}

\author{
Elina Salomaa, postdoctoral researcher \\ Department of Language and Communication Studies \\ Seminaarinkatu 15, 40014 University of Jyväskylä, Finland
}

\begin{abstract}
This dissertation presents the phenomenon of social television by focusing on the interplay between the traditional broadcast media and the newer social media in the context of the FIFA World Cup. The aim of the study is to shed light on interactional practices that are generated in the intersection of television and Twitter. Through the lens of digital discourse and conversation analysis the study examines how the participation in a media event is constructed in live tweeting practices. The dissertation shows that social media have offered new ways of participating and enjoying television content but have not replaced the role of traditional television as a central medium for experiencing massive media events such as the FIFA World Cup.
\end{abstract}

Keywords: social media, Twitter, television, live tweeting, social television, media event

\section{Introduction}

In the 21 st century, digital devices and social media have changed the roles of traditional audience and producer on a large scale. Today's media users are not just consumers of the media content but increasingly, by participating in its production in many ways, an integral part of it. This articlebased dissertation focuses on one interactive phenomenon typical of television in the digital age, socalled social television. Social television can be defined as the interplay between the traditional broadcast media and the newer social media; the practice of sending tweets (or other social media comments) about the TV show while watching it is an example (e.g. Selva 2016; Atifi \& Marcoccia 2017). The main objective of this study is to shed light on interactional practices in a digital environment in which television viewers are encouraged to participate in a media event in real time - both with other viewers and with the television show itself.

This practice of tweeting while watching TV, also referred to as live tweeting, has gained popularity especially during massive media events (Vaccari et al. 2015: 1041). This study focuses on the context of televised football by examining the Finnish national broadcasting company Yle's coverage of the FIFA World Cup 2014, as well as the tweets with the shared hashtag (\#ylemmfutis, '\#yleworldcup') offered by the media producer. 
In recent years there has been increasing interest in studying live tweeting, especially in the fields of media and cultural studies, and the results of these studies offer important insights into the types, styling or timing of tweets, as well as the functions and implications of live tweeting (e.g. Highfield et al. 2013; Vaccari et al. 2015; Selva 2016). However, what has not yet been explored is what participants actually $d o$ with the tweets in their interaction. This dissertation fills this gap by placing the phenomenon in the field of linguistics and analysing the material from an interactional perspective. This viewpoint makes it possible to answer questions such as how audiences are invited to participate in the media event, how viewers build interactions both with other viewers and with TV participants, and how they construct meanings about the media event and the experience of it as well as about the media they are using.

\section{Theoretical background}

The theoretical basis of the study is multidisciplinary, drawing on three approaches. Firstly, the literature of media events provides a context for the study, through which media are seen as a cultural and social space, where values, norms, and events are naturalised as a central part of society (e.g. Dayan \& Katz 1992; Couldry 2003). Secondly, the study lies in the field of media talk (e.g. Hutchby 2006; Tolson 2006) and is supported by the research of appropriation of media (e.g. Aya $\beta$ $\&$ Gerhardt 2012). These approaches have opened the way to examination not only of the interactive practices between television and its audience but also of the interaction among the active and interpretative audience. Thirdly, and most fundamentally, the study is based on multi-party technologically mediated communication between peers. The core of the dissertation is constructed around the tension generated by the clash between the unidirectional and restricted communication forms of broadcast media and the more open and interactive communication forms of social media.

With the help of these three approaches it is possible to form a framework that sheds light on the complex phenomenon of social television and participation therein. It offers the possibility of examining social television as multi-layered practices that are constructed in the interplay between the event, the media producer and live tweeting audiences. The study takes into account the fact that the technologies used in the interaction set some constraints and opportunities for action; the key question is how participants actually use these affordances to accomplish particular purposes (on affordances, see Hutchby 2001). Thus, the participation framework (Goffman 1981) of social television is pictured as a dynamic construction negotiated by participants turn by turn in their interaction. 


\section{Data and methods}

The data of the dissertation consists of six FIFA World Cup broadcasts in 2014 and the tweets the Finnish audience sent with the hashtag \#ylemmfutis during these matches. The tweets were collected manually from Twitter using the Twitter search tool. During the World Cup, it was common for Yle to show some of the tweets on the television screen, so the study materials also include the tweets unfolded on the television screen during all the 64 broadcasts. The total number of tweets examined was nearly 12000 . An essential point of the analysis was that the tweets were examined side by side with the broadcast to which they were contributing.

In order to understand the complex phenomenon of social television and the interactional practices around it, the study relies on digital discourse and conversation analysis, applying suitable tools and concepts from traditional discourse and conversation analysis to the analysis of digital contexts. The results of the study are reported in four articles, in each of which different tools are used in order to offer a new perspective on the phenomenon. The first article (Salomaa 2016) stresses the role of the audience by studying the discursive positions (Davies \& Harré 1990) live tweeters are offered by the media producer, as well as the ways tweeters accept or reject these ready-made roles. The second article (Salomaa \& Lehtinen 2018) focuses on the issue of media publicity by examining what happens in Twitter after one's tweet has unfolded on the television screen. Turn design (see Drew 2012) and adjacency pairs (see Schegloff \& Sacks 1973) are used to explicate how tweeters orient to each other, on the one hand, and to media publicity, on the other. In order to analyse the ways the Finnish audience adapts the global football narrative to the local context, the third substudy (Salomaa 2017) draws on the concept of recontextualization (Bauman \& Briggs 1990). The fourth study (Salomaa forthcoming) sums up the complex participation framework of social television by analysing the recipient design and sequence organisation (see Schegloff 2007; Drew 2012) of tweets that are addressed to the television.

\section{Findings}

The main findings of the study are two-fold. On the one hand, the analysis supports previous results that live tweeting practices, like many other digital practices, can challenge and blur the traditional division between audiences and producers. In particular, the study shows that the dichotomies of performer-audience, producer-consumer, celebrity-ordinary, and global-local are constantly in flux. The main reason for the changing roles is that live tweeters are not only the audience of the broadcast but also the producers of the live commentaries, so they can visibly react to the television events in real time and manage the positions they take as participants in the media event. The 
findings of the sub-studies show that live tweeters can take roles that have earlier been accessible only to journalists, experts or other media participants (see also Atifi \& Marcoccia 2017). That does not mean, however, that the more traditional roles of a viewer have vanished. In each game, viewers still want to pick a team to support in order to make it more exciting (Salomaa 2016). Also, as the third article shows, there is still room for a Finnish national and culturally-specific perspective despite the fact that the Finnish national team was not involved. Through their "blue and white glasses" tweeters were constructing the event as a meaningful narrative as well as building and maintaining their relations with other tweeters.

On the other hand, the analysis reveals that the same practices of live tweeting can strengthen the power of television. That is, in order to produce appropriate content for other live tweeters, the tweeters are forced to follow the broadcast as closely as possible (see also Selva 2016). In addition, the study reveals another significant proof of the powerful status of television in the context of a media event: when tweets were unfolded on the television screen, the tweeters acknowledged these tweets e.g. by congratulating or complimenting the tweeter, thus making the television presence a significant achievement (Salomaa \& Lehtinen 2018). Consistent with the results of previous studies, e.g. by van Es (2016), the dialogue between audience and television participants was no more than superficial. The tweets were used as an overlay for the broadcast rather than as interactional resources brought into the discussion. However, as the fourth sub-study shows, tweets addressed to television can be seen more as evaluating the action of television participants than as directives that genuinely attempt to control what journalists, players or experts say or do. Thus, through the possibility of addressing the television participants, tweeters seem to primarily construct solidarity with other tweeters as well as show themselves to be proper football watchers.

\section{Conclusion}

The findings of the dissertation indicate that social media have offered new ways of participating and enjoying television content but have not replaced the role of traditional television as a central medium for experiencing massive media events such as the FIFA World Cup. Instead, the media environment of today seems to be composed of various different media, which are used in cooperative and complementary ways. This means that previously invisible and unheard voices and perspectives can be raised in contexts where participation has traditionally been restricted.

The results of this study offer only a limited view of live tweeting, as the study focused only on the official hashtag and ignored the rival hashtags (e.g. \#mmfutis '\#worldcup). However, the chosen 
perspective offered important insights into the intersection between old and new media. The increasing role of technology in everyday life and, by implication, the deepening connections between different media forms, make it particularly important to study the fluid relations between participants, events and contexts. In the future, it would be worth studying sports events in the intersection between live experience, joint television watching and the digital contribution.

\section{References}

Atifi, Hassan/Marcoccia, Michel (2017): "Exploring the role of viewers' tweets in French TV political programs: Social TV as a new agora?” Discourse, Context \& Media 19:31-38.

Aya $\beta$, Ruth/Gerhardt, Cornelia eds. (2012): Appropriation of media in everyday life. Amsterdam: John Benjamins.

Bauman, Richard/Briggs, Charles (1990): "Poetics and performances as critical perspectives on language and social life." Annual Review of Anthropology 19:59-88.

Couldry, Nick (2003): Media rituals. A critical approach. London: Routledge.

Davies, Bronwyn/Harré, Rom (1990): "Positioning: The discursive production of selves." Journal for the Theory of Social Behaviours 20:43-63.

Dayan, Daniel/Katz, Elihu (1992): Media events. The live broadcasting of history. Cambridge: Harvard University Press.

Drew, Paul (2012): “Turn design.” The Handbook of Conversation Analysis. Eds. Jack Sidnell/Tanya Stivers. Oxford: Wiley-Blackwell. 131-149.

Goffman, Erving (1981): Forms of Talk. Philadelphia: University of Pennsylvania Press.

Highfield, Tim/Harrington, Stephen/Bruns, Axel (2013): “Twitter as a technology for audiencing and fandom." The \#Eurovision phenomenon. Information, Communication \& Society 16:315-339.

Hutchby, Ian (2001): Technologies, texts \& affordances. Sociology 35:441-456.

Hutchby, Ian (2006): Media talk: Conversation analysis and the study of broadcasting. Maidenhead: Open University Press.

Salomaa, Elina (2016): "Livetviittaaminen jalkapallon MM-kisojen mediaspektaakkelissa Sosiaalisen television faniutuva yleisö.” Media \& viestintä 39:137-160.

Salomaa, Elina (2017): "Tarinankerrontaa sinivalkoisin silmälasein: jalkapallon MM-kisojen glokalisointi television ja Twitterin vuorovaikutuksessa." Kulttuurintutkimus 34:3-14.

Salomaa, Elina (forthcoming): "'’Nyt Litti järki käteen!": Televisiolle suunnatut direktiivit \#ylemmfutis-tviiteissä." Virittäjä.

Salomaa, Elina/Lehtinen, Esa (2018): “"Congratulations, you're on TV!": Middle-space performances of live tweeters during FIFA World Cup." Discourse, Context \& Media 25:132-142.

Schegloff, Emanuel (2007): Sequence organization in interaction. A primer in conversation analysis. Volume 1. Cambridge: Cambridge University Press. 
Schegloff, Emanuel/Sacks, Harvey (1973): “Opening up closings”. Semiotica 8, 289-327.

Selva, Donatella (2016): "Social television. Audience and political engagement." Television \& New Media 17:159-173.

Tolson, Andrew (2006): Media talk: spoken discourse on TV and radio. Edinburgh: Edinburgh University Press.

Vaccari Cristian/Chadwick, Andrew/O'Loughlin, Ben (2015): "Dual Screening the Political: Media Events, Social Media, and Citizen Engagement." Journal of Communication 65:1041-1061.

van Es, Karin (2016): "Social TV and participation dilemma in NBC's the Voice." Television \& New Media 17:108-123. 